\title{
Chemical Synthesis of Interleukin-2 and Disulfide Stabilizing Analogues
}

\section{Journal Article}

Author(s):

Murar, Claudia E.; Ninomiya, Mamiko; Shimura, Satomi; Karakus, Ufuk; Boyman, Onur; Bode, Jeffrey W.

Publication date:

2020-05-25

Permanent link:

https://doi.org/10.3929/ethz-b-000408046

Rights / license:

In Copyright - Non-Commercial Use Permitted

Originally published in:

Angewandte Chemie. International Edition 59(22), https://doi.org/10.1002/anie.201916053

\section{Funding acknowledgement:}

150073 - Chemoselective Protein Ligation (SNF)

169451 - Protein Synthesis with Chemoselective Ligations (SNF) 


\title{
Chemical Synthesis of Interleukin-2 and Disulfide Stabilizing Analogues
}

\author{
Claudia E. Murar ${ }^{[a]+}$, Mamiko Ninomiya ${ }^{[a]+}$, Satomi Shimura ${ }^{[a]}$, Ufuk Karakus ${ }^{[b]}$, Onur Boyman ${ }^{[b]}$ \\ and Jeffrey W. Bode ${ }^{[a] \star}$
}

\begin{abstract}
Chemical protein synthesis allows the construction of well-defined structural variations and facilitates the development of deeper understanding of protein structure-function relationships and new protein engineering strategies. Here we report the chemical synthesis of interleukin-2 (IL-2) variants on a multimiligram scale and the formation of non-natural disulfide mimetics that improve stability against reduction. The synthesis was accomplished by convergent KAHA ligations; the acidic conditions of KAHA ligation proved to be valuable for the solubilization of the hydrophobic segments of IL-2. The bioactivity of the synthetic IL-2 and its analogues were shown to be equipotent to recombinant IL-2 and exhibit improved stability against reducing agents.
\end{abstract}

Disulfide bonds play an important role in protein folding and stability. ${ }^{[1]}$ They are essential for maintaining the threedimensional structure of a protein, which allows high-affinity interactions with specific targets. ${ }^{[2]}$ However, many disulfide bonds are prone to reduction and scrambling in vivo by glutathione or redox enzymes, ${ }^{[3]}$ resulting in the loss of the desired biological activity. Numerous strategies to replace disulfide bonds in biologically active peptides with more stable isosteres such as triazoles, ${ }^{[4]}$ thioethers ${ }^{[5]}$ and others ${ }^{[6]}$ have been reported. Some replacements provide more stable peptides that maintained their structure and activity. These concepts, however, have not been extended to improving the properties of therapeutic proteins other than insulin ${ }^{[5 d, 7]}$, despite well-known limitations in their stability, storage, and administration.

We chose interleukin-2 (IL-2) for our study on improving the stability of a protein by replacing the disulfide bond with more stable surrogates. IL-2 is one of the most important and wellstudied cytokines and is crucial for the body's natural response to microbial infection. ${ }^{[8,9]}$ It has multiple functions, for example stimulation of regulatory $T$ cells (Tregs) and stimulation of the effector cells (cytotoxic T cells or natural killer cells) ${ }^{[10]}$ and is an established treatment used for patients with metastatic renal cell carcinoma and metastatic melanoma. ${ }^{[10,11]}$ However, when

[a] Dr. C. E. Murar, M. Ninomiya, Dr. S. Shimura, Prof. Dr. J. W. Bode Laboratorium für Organische Chemie

Department of Chemistry and Applied Biosciences, ETH Zürich Vladimir-Prelog-Weg 3, 8093 Zürich (Switzerland)

E-mail: bode@org.chem.ethz.ch

[b] U. Karakus, Prof. Dr. O. Boyman

Department of Immunology, University Hospital Zurich, Gloriastrasse 23, 8091 Zürich (Switzerland)

[+] These authors contributed equally to this work.

Supporting information for this article is given via a link at the end of the document. administered, IL-2 has a short plasma half-life in the range of minutes (7-10 $\mathrm{min}$ in humans). Therefore, maintaining IL-2 at a level which is necessary to stimulate $T$ cell proliferation requires high doses of IL-2 or frequent administration, leading to toxicity and side effects. ${ }^{[12]}$

In this report, we document the multimiligram chemical synthesis of IL-2 and analogues by $\alpha$-ketoacid-hydroxylamine (KAHA) ligation. ${ }^{[13]}$ Key to the success of this synthesis is the unique nature of the KAHA ligation using 5-oxaproline, which operates under acidic conditions ideal for solubilizing hydrophobic C-terminal segments of IL-2 and delivers more soluble peptide esters as the primary ligation product. ${ }^{[14]}$ Using 5-oxaproline results in the introduction of homoserine, a noncanonical amino acid, at the ligation site, but when carefully chosen this mutation does not disturb the folding or biological activity of synthetic proteins. ${ }^{[15]}$ The synthetic route allowed facile incorporation of penicillamine residues ${ }^{[16]}$ and methylene thioacetal ${ }^{[17]}$ for the preparation of more stable IL-2 analogues.

Mature IL-2 contains 133-amino acid residues with a molecular weight of $15.4 \mathrm{kDa}$ and three cysteine residues (Cys58, Cys105, Cys125), two of which form a disulfide bond (Cys58-Cys105) that contributes to the overall tertiary structure and bioactivity. In 2015, the Hojo group reported the first chemical synthesis of IL-2 - after more than 15 years of efforts while our work was in progress. ${ }^{[18]}$ A major challenge in the synthesis of IL-2 is the preparation of the extremely hydrophobic region from residues 91-133. To overcome this problem, the Hojo group increased the isoelectric point of the peptide and facilitated the RP-HPLC purification and ligation by using picolyl ester protecting groups on the side-chain of Glu100/106/110/116. However, this method requires extra deprotection steps, and the overall synthetic yields were modest due to the formation of pyroglutamic acid during solid phase peptide synthesis (SPPS).

We completed the synthesis of IL-2 as part of a foursegment, three-ligation approach. Wild type IL-2 is glycosylated at Thr3, but the glycosylation does not appear to influence the activity of the protein. ${ }^{[19]}$ In this report, we prepared the nonglycosylated form of IL-2. We began with a careful examination of the amino acid sequence and structure of IL-2 and planned our ligation sites in such a way that the homoserines introduced by KAHA ligation would not interfere with the binding of IL-2 to receptors ${ }^{[20]}$ or modify any essential amino acids that have been shown to contribute to IL-2 bioactivity. ${ }^{[19]}$ Our approach identified three ligation sites: Leu40-Thr41, Leu70-Asn71 and Phe103Met104 (Scheme 1a), which introduced three homoserine (Hse, $\mathrm{T}^{\S}$ ) residues, Thr41Hse, Asn71Hse and Met104Hse. ${ }^{[21]}$ 
a) APTSSSTKKT QLQLEHLLLD LQMILNGINN YKNPKLTRML-TFKFYMPKKA TELKHLQCLE EELKPLEEVLL-2:

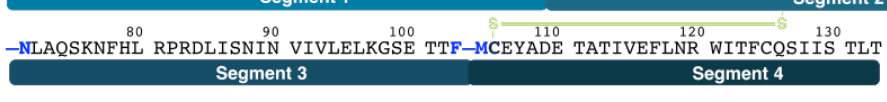

Mutations:

M23Nle, M39Nle, T41Hse, M46Nle, N71Hse, M104Hse
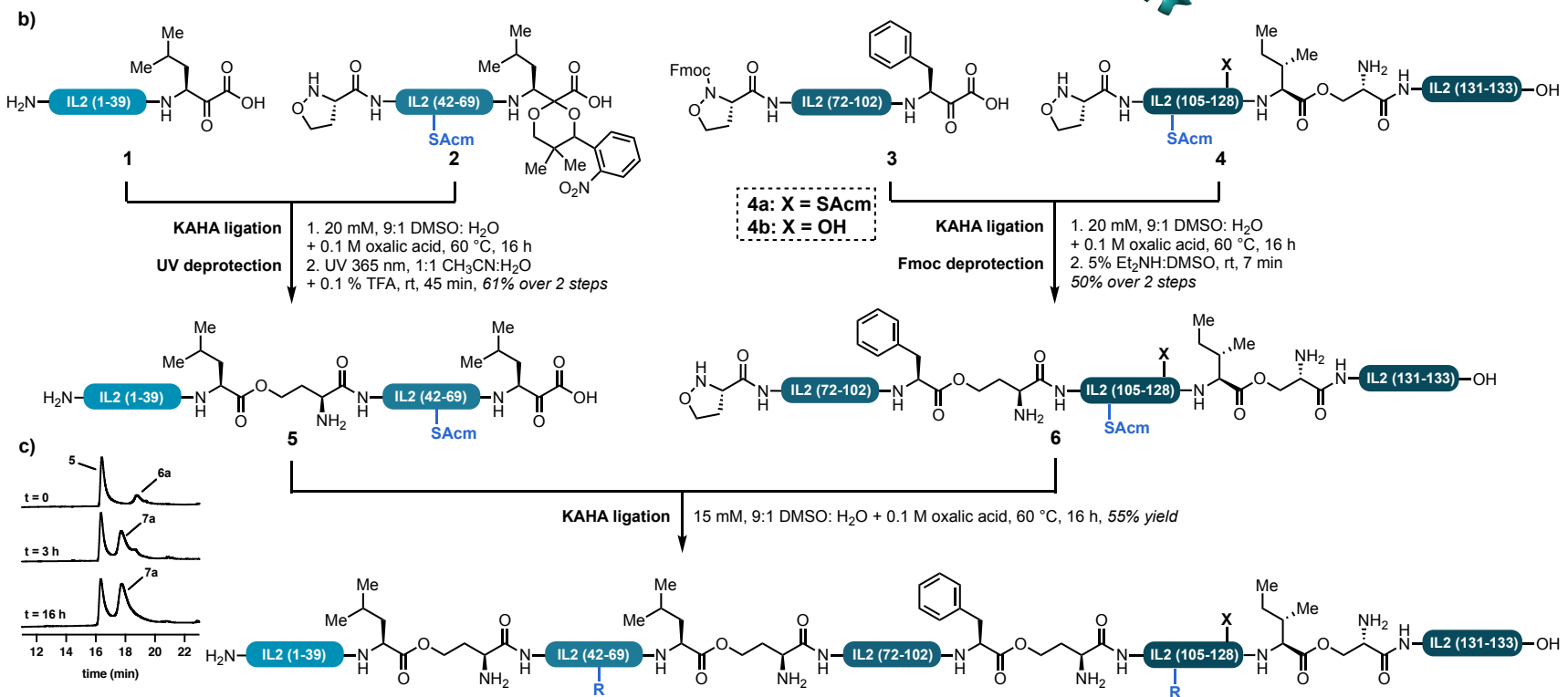

KAHA ligation $\mid 15 \mathrm{mM}, 9: 1 \mathrm{DMSO}: \mathrm{H}_{2} \mathrm{O}+0.1 \mathrm{M}$ oxalic acid, $60^{\circ} \mathrm{C}, 16 \mathrm{~h}, 55 \%$ yield
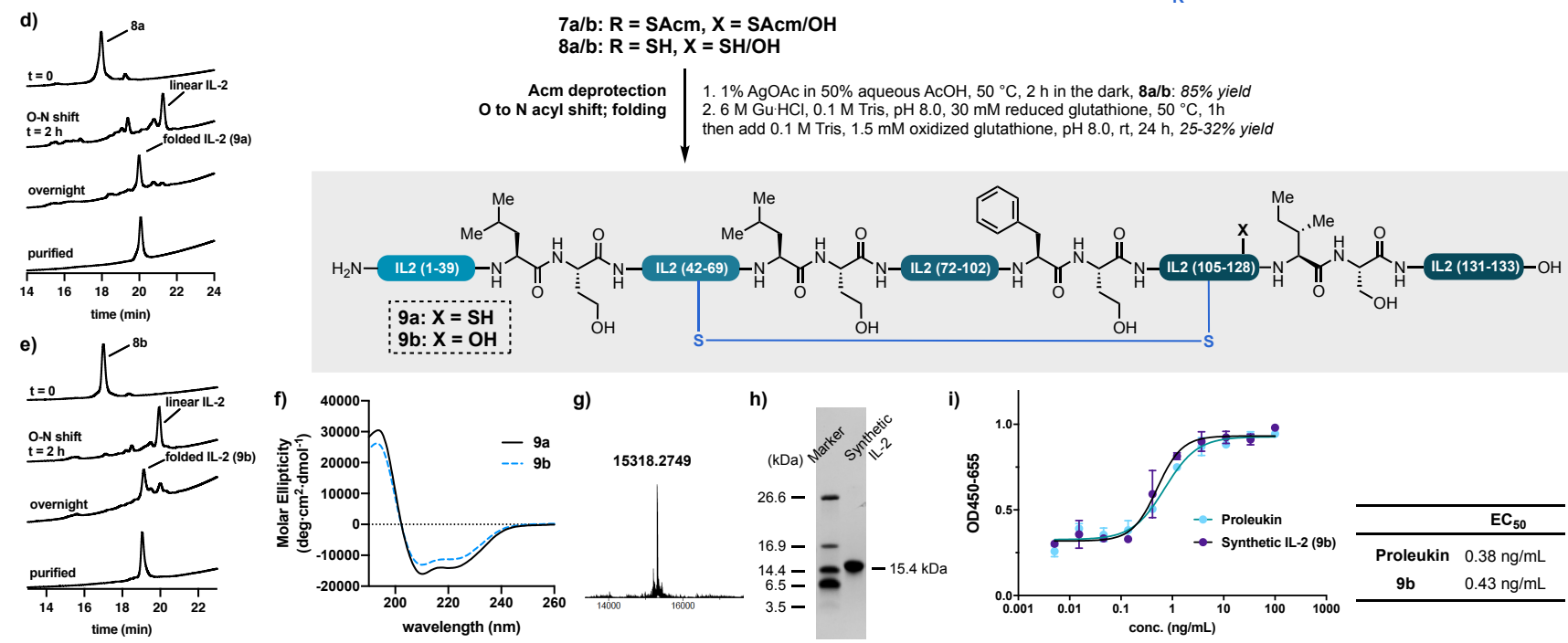

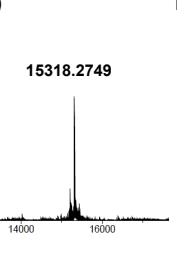

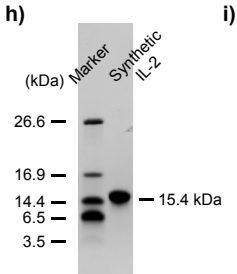

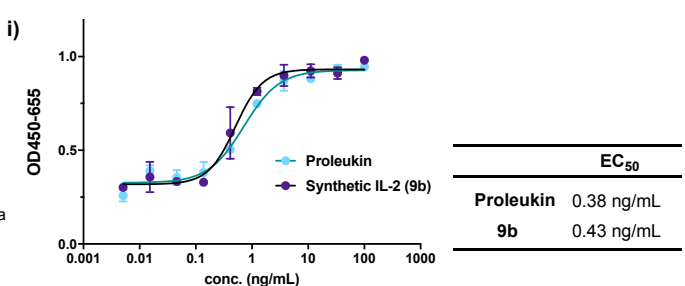

Scheme 1. a) Amino acid sequence of IL-2 showing the proposed ligation sites; b) Synthesis of IL-2 by a four-segment, three KAHA ligation strategy; c) Analytical HPLC monitoring of the ligation between 5 and $6 \mathbf{a}$ to give linear IL-2 7a; d) Analytical HPLC monitoring of the folding of polypeptide 8 a to give folded IL-2 9a; e) Analytical HPLC monitoring of the folding of polypeptide $\mathbf{8 b}$ to give folded IL-2 $\mathbf{9 b}$; f) CD spectra of folded IL-2 $\mathbf{9 a}$ and $\mathbf{9 b}$; g) ESI-HRMS of folded IL-2 $9 a$; h) SDSPAGE of folded IL-2 9a; i) CTLL-2 cell proliferation to compare bioactivity of Proleukin and synthetic variant $\mathbf{9 b}$.

We also substituted the three remaining methionine residues (Met23, Met39, Met46) with norleucines in order to avoid oxidation during handling, storage and folding. ${ }^{[22]}$ We envisaged incorporating protecting groups for the cysteine residues for better handling of the peptide segments. After evaluating both tert-butylthio $(\mathrm{StBu})^{[23]}$ and acetamidomethyl $(\mathrm{Acm})$ protecting groups, we selected Acm, whose removal is general and well established. ${ }^{[24]}$

As noted by Hojo, the preparation of the C-terminal segment 4 proved to be challenging due to its low water solubility, strong tendency to aggregate, and poor isolation by RP-HPLC. In order to address this issue, we introduced one pseudoproline Ala112Thr113 to disrupt the potential $\beta$-sheet formation during SPPS ${ }^{[25]}$ and one isoacylpeptide lle129-Ser130 to enhance its solubility. ${ }^{[26]}$ Double couplings and cappings were also employed after each amino acid residue. As a result, we were pleased to see that starting with one gram of resin $(0.25 \mathrm{mmol} / \mathrm{g})$ we isolated $60 \mathrm{mg}$ of the purified peptide 4 bearing an $\mathrm{N}$-terminal 5oxaproline $(7 \%$ overall yield). We attempted to improve the synthesis of 4 by building the $C$-terminal segment on a ChemMatrix resin derivatized with a Thr-HMBA-pentaarginine ${ }^{[27]}$ 
or by conducting the couplings at $60^{\circ} \mathrm{C}$, but these attempts did not lead to improvements.

Two variants of segment 4 were prepared $-4 a$ with the wildtype Cys 125 and $\mathbf{4 b}$, with Ser125, as found in the clinically used IL-2 Proleukin (Scheme 1b). Protein segments $\mathbf{1}$ and $\mathbf{2}$ were readily synthesized by our established procedures for the FmocSPPS for protected peptide $\alpha$-ketoacids ${ }^{[28]}$ on Rink-Amide polystyrene resin preloaded with Fmoc-Leu-protected- $\alpha$-ketoacid or Fmoc-Leu-photoprotected- $\alpha$-ketoacid. Cleavage of the peptides from the resin and purification by RP-HPLC gave 200 $300 \mathrm{mg}$ of desired peptide segments 1 and 2 in good yield (20$24 \%$ based on the loading of the starting resin). Segment 3 was prepared by Fmoc-SPPS on Rink-Amide ChemMatrix resin preloaded with Fmoc-Phe-protected- $\alpha$-ketoacid. Importantly, for this segment, the use of a polyethyleneglycol based resin (ChemMatrix) gave a better yield than polystyrene resin. This segment was obtained in $>100 \mathrm{mg}$ and $15 \%$ yield based on the loading of the resin.

Segment 1 and segment 2 were coupled under standard KAHA ligation conditions (15 mM, 9:1 DMSO: $\mathrm{H}_{2} \mathrm{O}, 0.1 \mathrm{M}$ oxalic acid, $60^{\circ} \mathrm{C}$ ) at $>100 \mathrm{mg}$ scale to furnish the peptide intermediate in $16 \mathrm{~h}$. The ligation mixture was diluted to $1 \mathrm{mM}$ with $\mathrm{CH}_{3} \mathrm{CN}: \mathrm{H}_{2} \mathrm{O}$ 1:1, and irradiated at $365 \mathrm{~nm}$ for $45 \mathrm{~min}$ to furnish 5 in $62 \%$ yield over ligation and one pot UV irradiation. KAHA ligation between $\mathbf{3}$ and $\mathbf{4 a - b}$ was carried out using standard conditions. We were pleased to see that the reaction cleanly afforded the Fmoc-protected ligation product overnight. Without any purification, the ligation mixture was diluted with DMSO and subjected to one pot Fmoc-deprotection with $5 \%$ diethylamine for $8 \mathrm{~min}$ to yield $\sim 80 \mathrm{mg}$ of the desired product 6 (6a and $\mathbf{6 b}$ ) in $50-53 \%$ isolated yield for ligation and Fmoc-deprotection. All backbone peptide esters formed during the KAHA ligation were preserved just before the folding to ensure the solubilization of the peptide segments during sequential assembly to the linear protein.

The final ligation between 5 and $\mathbf{6}$ (6a or $\mathbf{6 b}$ ) was performed under standard KAHA ligation conditions at $>50 \mathrm{mg}$ scale for 16 $\mathrm{h}$ to cleanly afford the peptides $7 \mathrm{a}$ and $\mathbf{7 b}$ in $55 \%$ isolated yield (Scheme 1c). We were pleased to see that the synthesis of linear IL-2 was successful by KAHA ligation, in $28 \%$ overall yield, and we obtained $>50 \mathrm{mg}$ of linear protein in reproducible yields.

The Acm-deprotection of $\mathbf{7 a}$ or $\mathbf{7 b}$ was performed by treatment with $\mathrm{AgOAc}$ in $50 \%$ aqueous $\mathrm{AcOH}$ for $2 \mathrm{~h}$ at $50{ }^{\circ} \mathrm{C}$ in the dark. ${ }^{[18]}$ The deprotection reaction proceeded efficiently and gave the completely deprotected IL-2 containing four peptide esters $\mathbf{8 a}$ or $\mathbf{8 b}$ in $\mathbf{7 5 \%}$ isolated yield on more than $25 \mathrm{mg}$ scale. Prior to the folding process, the peptide esters were converted into the peptide bonds, by treatment with a reducing buffer containing $6 \mathrm{M} \mathrm{Gn} \cdot \mathrm{HCl}, 0.1 \mathrm{M}$ Tris, and $30 \mathrm{mM}$ reduced glutathione $(\mathrm{pH} 8.0)$, for $2 \mathrm{~h}$ at $50^{\circ} \mathrm{C}$. The solution was then diluted with $0.1 \mathrm{M}$ Tris containing $1.5 \mathrm{mM}$ oxidized glutathione, and the resulting solution was kept for $24 \mathrm{~h}$ at $\mathrm{rt.}^{[18]}$ One indication that the protein folding is complete is the significant HPLC shift (Scheme 1d,e). Purification by RP-HPLC gave final folded proteins $9 \mathrm{a}$ or $\mathbf{9 b}$ in $25-32 \%$ isolated yield for rearrangement and folding, resulting in $2-3 \mathrm{mg}$ of protein. The final, folded protein was characterized by analytical HPLC, CD spectrum, ESI-HRMS and SDS-PAGE. (Scheme 1d,e,f,g,h).

We chose to continue with protein $9 \mathbf{b}$ for our bioactivity studies and for the comparison study with the IL-2 analogues described below in this document. The bioactivity of $\mathbf{9 b}$ in respect to Proleukin was evaluated by measuring CTLL-2 cell proliferation in response to IL-2 stimulation. We were pleased to see that $\mathrm{EC}_{50}$ values of Proleukin and $\mathbf{9 b}$ were comparable $(0.38$ $\mathrm{ng} / \mathrm{mL}, 0.43 \mathrm{ng} / \mathrm{mL}$, respectively, Scheme 1i).

Using the same flexible synthetic strategy, we aimed to replace Cys residue with penicillamine (Pen), which is known to form more stable disulfide bonds ${ }^{[29]}$ or the replacement of the disulfide bond with methylene thioacetal. At the outset of our studies we envisaged the synthesis of three IL-2 surrogates (Cys58Pen; Cys105Pen; and Cys58Pen \& Cys105Pen) - two containing one Pen residues each and one with two Pen residues (Scheme 2a). For these surrogates, Cys125 was replaced with Ser125 in order to avoid misfolding of the final protein. For the Pen analogues, we synthesized the corresponding peptide segments with the Pen residues. Using the same synthetic strategy described above, we were able to prepare between 15-25 mg of linear variants (Cys-Pen and PenCys surrogates) 10 and 11. A portion of the linear analogues were folded to afford between $0.3-0.8 \mathrm{mg}$ of folded 12 and 13 . The folding yields for these analogues were modest, between $10-15 \%$, which may be due to slow formation of the Cys-Pen disulfide bond. The Pen-Pen analogue could not be folded in reasonable quantities for the assays. The CD spectra of folded 12 and 13 were comparable to the reported IL-2 CD spectrum (Scheme 2c). ${ }^{[18]}$

In addition, we also prepared an IL-2 analogue bridged by a methylene thioacetal, which is known to enhance the stability under reductive conditions with little structural disturbance. ${ }^{[17]}$ This analogue was prepared from folded IL-2 9b (Cys125Ser) by reduction and subsequent alkylation of the thiols using $\mathrm{CH}_{2} \mathrm{I}_{2}$ in aqueous solution. While the reaction with $9 \mathrm{~b}$ gave the desired alkylated product 14 , the reaction with 9a (Cys125) led to multiple alkylation. 
a)


11

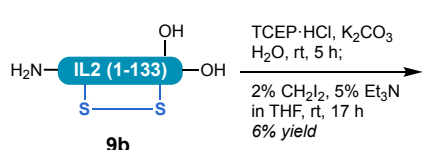

$9 b$

surrogate

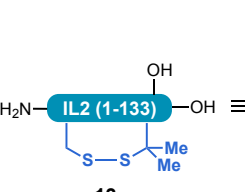

13

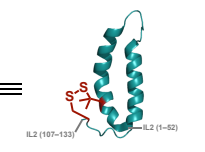

Cysteine-Penicillamine
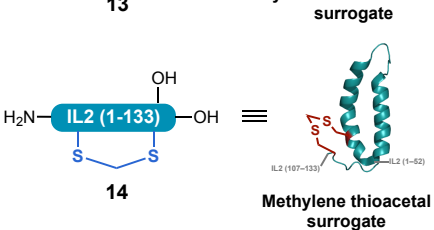

b)

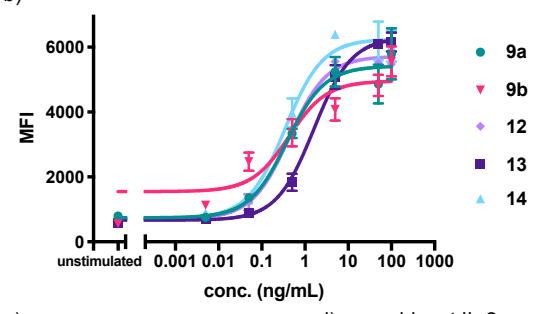

$$
\begin{array}{cc}
\hline & \mathrm{EC}_{50} \\
\hline 9 a & 0.38 \mathrm{ng} / \mathrm{mL} \\
9 b & 0.43 \mathrm{ng} / \mathrm{mL} \\
12 & 0.43 \mathrm{ng} / \mathrm{mL} \\
13 & 1.6 \mathrm{ng} / \mathrm{mL} \\
14 & 0.35 \mathrm{ng} / \mathrm{mL} \\
\hline
\end{array}
$$
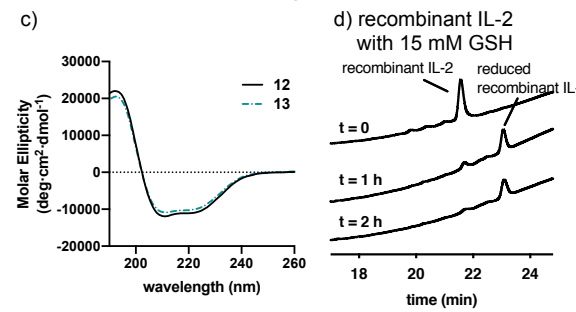

Scheme 2. a) Acm deprotection and folding to give IL-2 variants 12, 13 and 14; b) pSTAT-5 assays to compare bioactivity of synthetic variants with CTLL-2 cells; c) CD spectra of folded IL-2 analogues: 12 and 13; d) recombinant IL-2 in PBS buffer, pH 7.2 with 15 mM reduced glutathione; e) 12 in PBS buffer, pH 7.2 with 15 $\mathrm{mM}$ reduced glutathione.

We evaluated the bioactivity of our analogues in comparison with our synthetic IL-2 proteins by measuring phosphorylated STAT5 (pSTAT5 assay) in response to IL-2 stimulation on CTLL-2 cells (Scheme 2b). ${ }^{[30]}$ Analogue 12 and 14 showed similar $\mathrm{EC}_{50}$ values to $9 \mathbf{a}$ and $\mathbf{9 b}(0.43 \mathrm{ng} / \mathrm{mL}, 0.35 \mathrm{ng} / \mathrm{mL})$ while analogue 13 showed lower activity ( $\left.E_{50}: 1.6 \mathrm{ng} / \mathrm{mL}\right)$. We subjected recombinant IL-2 and the most active penicillamine IL2 analogue 12 to physiological reducing conditions using $15 \mathrm{mM}$ reduced glutathione in PBS buffer at $\mathrm{pH}$ 7.2. While recombinant IL-2 was substantially reduced after $1 \mathrm{~h}$ upon being subjected to glutathione conditions (Scheme 2d), the penicillamine-cysteine IL-2 analogue 12 showed improved stability (Scheme 2e). As anticipated from the peptide literature ${ }^{[29]}$, the replacement of even just one cysteine residue for penicillamine in a disulfide bond results in improvement of stability against reduction.

In summary, we have developed a versatile approach for the chemical synthesis of biologically active IL-2 variants. The material prepared by convergent KAHA ligations could be readily folded to give synthetic IL-2 with good overall yield; the biological activity of the synthetic IL-2 has been confirmed by proliferation assay. With the same synthetic strategy, we could modify IL-2 and replaced the Cys58-Cys 105 disulfide bond with penicillamine-cysteine bond or methylene thioacetal. The activity of the folded proteins was tested and shown to be similar to the recombinant version; Pen58-Cys105 analogue 12 showed improved stability against reduction. This work establishes that chemical protein synthesis offers a viable approach to bringing the insights in the design and stabilization of peptide therapeutics to the modern challenge of engineering more advanced protein therapeutics.

\section{Acknowledgements}

This work was supported by the ETH Zurich and the SNSF $(150073,169451)$. We thank the LOC MS service for analyses.

Keywords: chemical protein synthesis $\cdot$ interleukin-2 - KAHA ligation $\cdot$ protein modifications $\cdot$ disulfide bond

[1] a) T. E. Creighton, Prog. Biophys. Mol. Biol. 1979, 33, 231-297; b) S. F. Betz, Protein Sci. 1993, 2, 1551-1558; c) W. J. Wedemeyer, E. Welker, M. Narayan, H. A. Scheraga, Biochemistry 2000, 39, 4207-4216.

[2] G. E. Schulz, R. H. Schirmer, Principles of Protein Structure, Springer, New York, 1979

[3] a) H. F. Gilbert, Methods Enzymol. 1995, 251, 8-28; b) A. Holmgren, M. Björnstedt, Methods Enzymol. 1995, 252, 199-208.

[4] a) K. Holland-Nell, M. Meldal, Angew. Chem. Int. Ed. 2011, 50, 52045206; Angew. Chem. 2011, 123, 5310-5312; b) M. Empting, O. Avrutina, R. Meusinger, S. Fabritz, M. Reinwarth, M. Biesalski, S. Voigt, G. Buntkowsky, H. Kolmar, Angew. Chem. Int. Ed. 2011, 50, 52075211; Angew. Chem. 2011, 123, 5313-5317; c) A. Gori, C.-I. A. Wang, P. J. Harvey, K. J. Rosengren, R. F. Bhola, M. L. Gelmi, R. Longhi, M. J. Christie, R. J. Lewis, P. F. Alewood, A. Brust, Angew. Chem. Int. Ed. 2015. 54, 1361-1364; Angew. Chem. 2015, 127, 1378-1381; d) G. M. Williams, K. Lee, X. Li, G. J. S. Cooper, M. A. Brimble, Org. Biomol. Chem. 2015,13, 4059-4063; e) S. R. Tala, A. Singh, C. J. Lensing, S. M. Schnell, K. T. Freeman, J. R. Rocca, C. Haskell-Luevano, ACS Chem. Neurosci. 2018, 9, 1001-1013.

[5] a) J. Bondebjerg, M. Grunnet, T. Jespersen, M. Meldal, ChemBioChem 2003, 4, 186-194; b) Z. Dekan, I. Vetter, N. L. Daly, D. J. Craik, R. J. Lewis, P. F. Alewood, J. Am. Chem. Soc. 2011, 133, 15866-15869; c) P. J. Knerr, A. Tzekou, D. Ricklin, H. Qu, H. Chen, W. A. van der Donk, J. D. Lambris, ACS Chem. Biol. 2011, 6, 753-760; d) J. A. Karas, N. A. Patil, J. Tailhades, M.-A. Sani, D. B. Scanlon, B. E. Forbes, J. Gardiner, F. Separovic, J. D. Wade, M. A. Hossain, Angew. Chem. Int. Ed. 2016, 55, 14743-14747; Angew. Chem. 2016, 128, 14963-14967.

[6] For a review see: A. Gori, P. Gagni, S. Rinaldi, Chem. Eur. J. 2017, 23, 14987-14995.

[7] a) B. van Lierop, S. C. Ong, A. Belgi, C. Delaine, S. Andrikopoulos, N. L. Haworth, J. G. Menting, M. C. Lawrence, A. J. Robinson, B. E. Forbes, 
Sci. Rep. 2017, 7, 17239; b) S. C. Ong, A. Belgi, B. van Lierop, C. Delaine, S. Andrikopoulous, C. A. MacRaild, R. S. Norton, N. L. Haworth, A. J. Robinson, B. E. Forbes, J. Biol. Chem. 2018, 293 , 11928-11943; c) O. Weil-Ktorza, N. Rege, S. Lansky, D. E. Shalev, G. Shoham, M. A. Weiss, N. Metanis, Chem. Eur. J. 2019, 25, 8513-8521.

[8] a) T. Taniguchi, H. Matsui, T. Fujita, C. Takaoka, N. Kashima, R. Yoshimoto, J. Hamuro, Nature 1983, 302, 305-310; b) S. A. Rosenberg E. A. Grimm, M. McGrogan, M. Doyle, E. Kawasaki, K. Koths, D. F. Mark, Science 1984, 223, 1412-1414

[9] a) K. A. Smith, Science 1988. 240, 1169-1176; b) T. A. Waldmann, Nat Rev. Immunol. 2006, 6, 595-601; c) T. R. Malek, Annu. Rev. Immunol. 2008, 26, 453-479; d) T. R. Malek, I. Castro, Immunity 2010, 33, 153165; e) O. Boyman, J. Sprent, Nat. Rev. Immunol. 2012, 12, 180-190; f) W. Liao, J.-X. Lin, W. J. Leonard, Immunity 2013, 38, 13-25; g) R. Spolski, P. Li, W. J. Leonard, Nat. Rev. Immunol. 2018, 18, 648-659.

[10] a) J. E. Talmadge, H. Phillips, J. Schindler, H. Tribble, R. A. Pennington, Cancer Res. 1987, 47, 5725-5732; b) S. A. Rosenberg, M. T. Lotze, L. M. Muul, A. E. Chang, F. P. Avis, S. Leitman, W. M. Linehan, C. N Robertson, R. E. Lee, J. T. Rubin, C. A. Seipp, C. G. Simpson, D. E. White, N. Engl. J. Med. 1987, 316, 889-897.

[11] a) T. Jiang, C. Zhou, S. Ren, Oncoimmunology 2016, 5, e1163462; b) J. I. Clark, K. A. Margolin, Immunotherapy of Cancer. Cancer Drug Discovery and Development, (Ed.: M. L. Disis), Humana Press, Totowa New Jersey, 2006, pp. 355-364.

[12] a) M. B. Atkins, M. T. Lotze, J. P. Dutcher, R. I. Fisher, G. Weiss, K. Margolin, J. Abrams, M. Sznol, D. Parkinson, M. Hawkins, C. Paradise, L. Kunkel, S. A. Rosenberg, J. Clin. Oncol. 1999, 7, 2105-2116; b) J. P. Siegel, R. K. Puri, J. Clin. Oncol. 1991, 9, 694-704.

[13] a) T. J. Harmand, C. E. Murar, J. W. Bode, Nat. Prot. 2016, 11 1130-1147; b) V. R. Pattabiraman, A. O. Ogunkoya, J. W. Bode, Angew. Chem. Int. Ed. 2012, 51, 5114-5118; Angew. Chem. 2012, 124 5204-5208.

[14] T. G. Wucherpfennig, F. Rohrbacher, V. R. Pattabiraman, J. W. Bode, Angew. Chem. Int. Ed. 2014, 53, 12244-12247; Angew. Chem. 2014, 126, 12441-12444.

[15] a) C. He, S. S. Kulkarni, F. Thuaud, J. W. Bode, Angew. Chem. Int. Ed. 2015, 54, 12996-13001; Angew. Chem. 2015, 127, 13188-13193; b) T. G. Wucherpfennig, S. Müller, C. Wolfrum, J. W. Bode, Helv. Chim. Acta 2016, 99, 897-907; c) F. Rohrbacher, A. Zwicky, J. W. Bode, Chem. Sci. 2017, 8, 4051-4055; d) G. N. Boross, S. Shimura, M. Besenius, N.
Tennagels, K. Rossen, M. Wagner, J. W. Bode, Chem. Sci. 2018, 9 , 8388-8395.

[16] Y. Zheng, L. Zhai, Y. Zhao, C. Wu, J. Am. Chem. Soc. 2015, 137, 15094-15097.

[17] C. M. B. K. Kourra, N. Cramer, Chem. Sci. 2016, 7, 7007-7012.

[18] Y. Asahina, S. Komiya, A. Ohagi, R. Fujimoto, H. Tamagaki, K. Nakagawa, T. Sato, S. Akira, S. Takao, A. Ishii, Y. Nakahara, H. Hojo, Angew. Chem. Int. Ed. 2015, 54, 8226-8230; Angew. Chem. 2015, 127, 8344-8348.

[19] G. Ju, L. Collins, K. L. Kaffka, W.-H. Tsien, R. Chizzonite, R. Crowl, R. Bhatt, P. L. Kilian, J. Biol. Chem. 1987, 262, 5723-5731.

[20] X. Wang, M. Rickert, K. C. Garcia, Science 2005, 310, 1159-1163.

[21] L. Y. Yampolsky, A; Stoltzfus, Genetics 2005, 170, 1459-1472.

[22] A.-M. Gilles, P. Marlière, T. Rose, R. Sarfati, R. Longin, A. Meier, S. Fermandjian, M. Monnot, G. N. Cohen, O. Bârzu, J. Biol. Chem. 1988, 263, 8204-8209.

[23] U. Weber, P. Hartter, Hoppe-Seyler's Z. Physiol. Chem. 1970, 351, 1384-1388.

[24] T. Durek, V. Y. Torbeev, S. B. H. Kent, Proc. Natl. Acad. Sci. U.S.A. 2007, 104, 4846-4851.

[25] a) T. Haack, M. Mutter, Tetrahedron Lett. 1992, 33, 1589-1592; b) T. Wöhr, F. Wahl, A. Nefzi, B. Rohwedder, T. Sato, X. Sun, M. Mutter, J. Am. Chem. Soc. 1996, 118, 9218-9227.

[26] Y. Sohma, T. Yoshida, A. Taniguchi, T. Kimura, Y. Hayashi, Y. Kiso, Biopolymers 2007, 88, 253-262.

[27] M. A. Hossain, A. Belgi, F. Lin, S. Zhang, F. Shabanpoor, L. Chan, C Belyea, H. Truong, A. R. Blair, S. Andrikopoulos, G. W. Tregear, J. D. Wade, Bioconjugate Chem. 2009, 20, 1390-1396

[28] a) T. G. Wucherpfennig, V. R. Pattabiraman, F. R. P. Limberg, J. RuizRodríguez, J. W. Bode, Angew. Chem. Int. Ed. 2014, 53, 12248-12252; Angew. Chem. 2014, 126, 12445-12449; b) F. Thuaud, F. Rohrbacher, A. Zwicky, J. W. Bode, Helv. Chim. Acta. 2016, 99, 868-894.

[29] a) H. I. Mosberg, R. Hurst, V. J. Hruby, K. Gee, H. I. Yamamura, J. J. Galligan, T. F. Burks, Proc. Natl. Acad. Sci. U.S.A. 1983, 80, 58715874 ; b) O. H. Drummer, L. Routley, N. Christophidis, Biochem. Pharmacol. 1987, 36, 1197-1201; c) K. Rajarathnam, B. D. Sykes, B. Dewald, M. Baggiolini, I. Clark-Lewis, Biochemistry 1999, 38, 76537658; d) M. D. Ericson, K. G. Rice, Tetrahedron Lett. 2013, 54, 34403443.

[30] J.-X. Lin, W. J. Leonard, Oncogene 2000, 19, 2566-2576. 


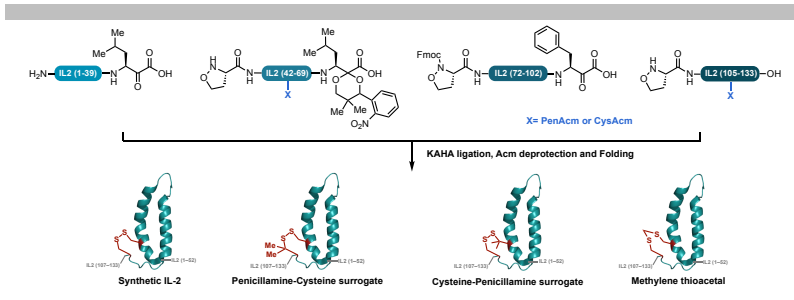

C. E. Murar, M. Ninomiya, S. Shimura,

U. Karakus, O. Boyman J. W. Bode*

Page No. - Page No.

Chemical Synthesis of Interleukin-2 and Disulfide Stabilizing Analogues

Penicillin shot - Convergent, ester-forming KAHA ligations under acidic conditions facilitate the assembly of the hydrophobic cytokine interleukin-2. This flexible strategy allows the preparation of more stable disulfides analogues constructed from the non-cannonical amino acid penicillamine. 